を確保できる。青海鉱山のような豪雪地帯では冬期採掘 休止期間中の粗鉣ストックとして重要である。純採掘費 を比較すれば大発破が最も安価であるが，自然地形によ る影響も大きくかつ爆落石のトラック運搬費が大幅に加 算されるので最終コストは高くなつている。大発破爆薬 を AN-FOに切替えたことによつて大幅なコストダウン
を計り，99\%発破にて爆薬㶳の60\%ダウンに成功した。 大発破採掘の最大の問題は発破工事でなく, 発破後の爆 落石の攻め出し小割作業である。したがつて発破計画は 爆落石の堆積高を低くし, 攻出し作業をできるだけ無 くするようにしている。今後大発破採掘は大坑井設備の. 早期育成により漸次消化して減量する予定である。

\title{
香春鉱山における $\mathrm{AN}-\mathrm{FO}$ の利用
}

\section{1. 緒 言}

当鉱山については香春鉣山階段採掘法として， 日本鉣業会誌1964年 3 月号に発表されているので 概況についての詳細は省くことにする。

主要設備 : 第 1 図香春鉣山系統図, 同付表に設 備の諸元を示す。

\section{2. 採 鉱}

切羽の設定 : 切羽の進行方向は, 立坑位置, 閃 緑岩, 玢岩の入り方, 断層線の方向, 登山道路の 位置，鉱山の立地条件（当鉣山（香春一の岳）山 頂にあつた香春城を中心として香春町が発達して いる)，排水等の要素を検討した結果, 第 2 図に示 すように東西方向に切羽面を設定し，立坑側すな わち南より北に向かつて進行している。

現在進行中の $402 \mathrm{~m}$ レベルは面積で 9 万 $\mathrm{m}^{2}$ の平 坦地で切羽長は最大 $370 \mathrm{~m}$, 平均 $250 \sim 300 \mathrm{~m}$ であ るから需要は 1 段ベンチで充分まかないきれる が，ベンチダウンが完了し切羽の拡大中には，2 段の形になる。

穿孔：昭和 37 年 2 月よりクローラドリルによる 本格的な階段採掘（ベンチの高さ $10 \mathrm{~m}$ ) を開始し た。

イ・バックブレークが少ない。

口. 切羽面が $45^{\circ}$ の斜面となるので保安上危険がない。 等の理由から $45^{\circ}$ の傾斜穿孔を単列に行ない（古河 $\mathrm{CR}$ D-2型を使用)，これには $65 \mathrm{~mm}$ のビット，32mm の角 ロッドを使用していたが，古河 CRD-8 型では $75 \mathrm{~mm}$ の ビット， $38 \mathrm{~mm}$ の角ロッド( 1 本 $26.2 \mathrm{~kg}$ )を最初傎用し, 次いで $65 \mathrm{~mm}$ のビット, $38 \mathrm{~mm}$ の丸ロッド ( 1 本 23.6 $\mathrm{kg}$ ) を使用（取扱いに便利で穿孔能率を上昇せしめる） して現在に至つている(第3図)。

* 日本七メント株式会社香春工場採掘課長

\section{石川久治郎*}

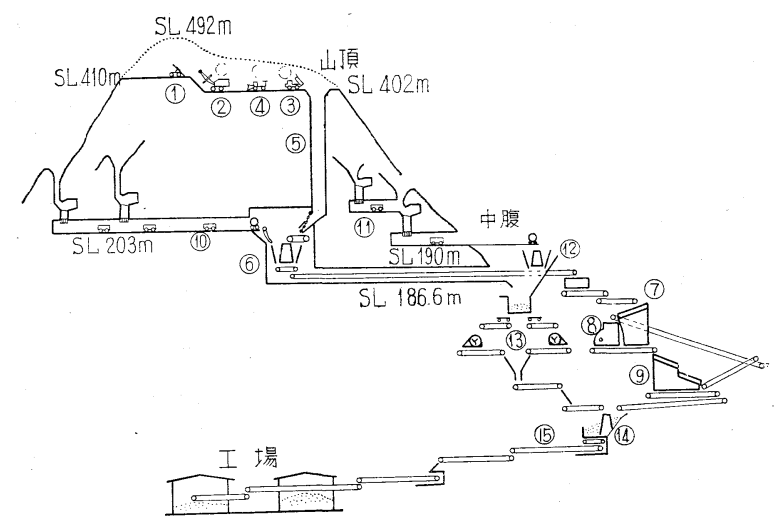

第1図 香春鉱山系統図

第 1 図付表 機械設備諸元

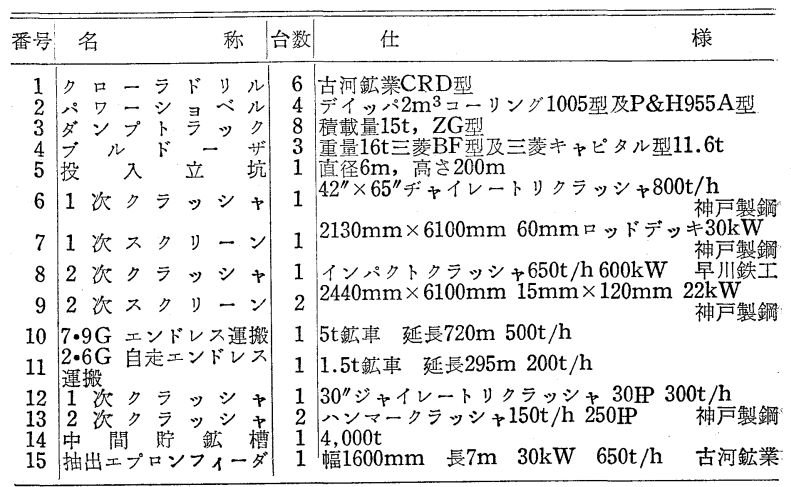

発破 : 現在行なつている当鉱山の発破作業を大別する とクローラドリルによる1 次発破，1 次発破で発生した 大塊 ( 1 次クラッシャの給鉣口とショベルディッパの大 きさは両者とも略 $1 \mathrm{~m}$ で見合つている。したがつてディ ッパを通らない砕石は小割を必要とする。この個数は最 近の実績では，起砕 $\mathrm{t}$ 数の6〜7\%である。)を処理する小 割発破, および進行切羽の端部処理（浮石の処理をも含 む）の発破，と３つに大別することができる。どの発破 に対しても, 山頂より逐次ベンチダウンする階段採掘法 


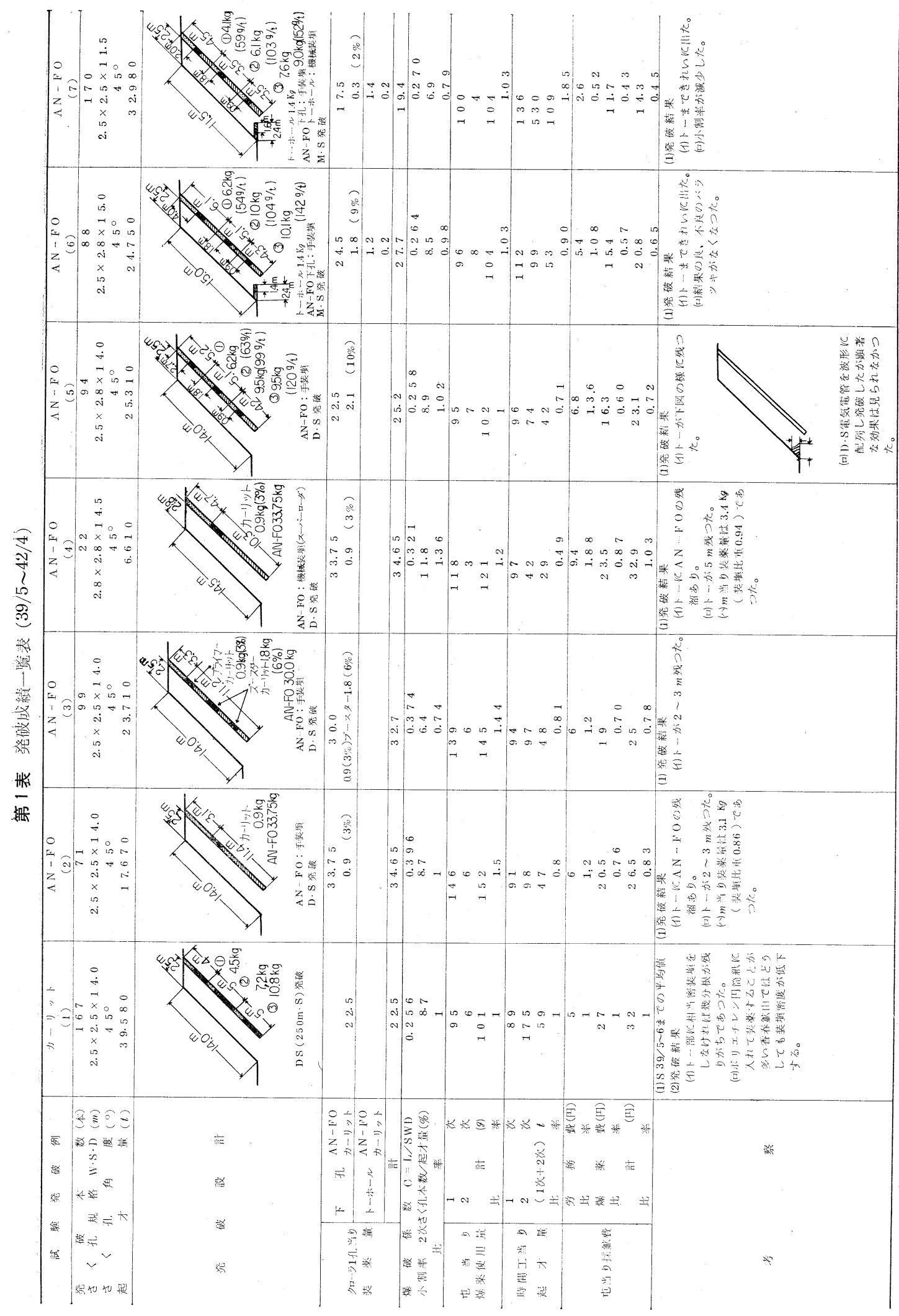


を採用しているので，周辺に対して飛石および転 落石の防止には宿命的なものがある。したがつて 発破設計に対しては弱装薬といらかたちで現われ てくる。

これらの発破で昭和 39 年 6 月よりカーリットを $\mathrm{AN}-\mathrm{FO}$ (日本カーリット社製) に切換元始め現在 では月平均95\%と使用限度まで消費している。

\section{3. クローラ発破における $\mathrm{AN}-\mathrm{FO}$ の利用}

経過: 39年 6 月にAN-FO 10函購入して試験し て以来現在では完全に AN-FO 切換えに成功した ので，その使用経過につき従来のカーリットと比 較してみると次の通りである。

(1) カーリット：最小抵抗線 $2.5 \mathrm{~m}$ ，穿孔間 隔2.5m, 3 段分散装薬, MS またはD S 発破し, $\mathrm{t}$ 当り装薬量も 1 次で $95 \mathrm{~g}$, 爆破係数 0.256 で使 用していた。

(2) AN-FO : 先ず AN-FO 使用に際して問 題となつたことは

（i）分散装薬の手間をなくすために集中装薬 した場合 $\mathrm{t}$ 当り爆薬使用量の大幅増加が予想され るが，その対策として穿孔規格がじこまで拡大で きるか。

(ii）当鉱山のように亀裂, ガマの多い所で AN-FO を使用するにはどうすればよいか。 であつた。種々試験の結果

（イ）穿孔規格 $\mathrm{W} \times \mathrm{S}$ をそれぞれ $2.5 \mathrm{~m}$ から $3 \mathrm{~m}$ に拡大してみたが, 発破効果の点よりみてカ ーリット以上に拡げることは無理なようである。 したがつて現行は $2.5 \mathrm{~m} \times 2.5 \mathrm{~m}$ で行なつている。

（口） 孔径 $65 \mathrm{~mm}$ では 7 8mくらいは確実に 完爆するが，それ以上になるとむらがあり ANFO の残留がみられた。この場合 $50 \mathrm{~mm} \phi \times 900 \mathrm{~g}$ の黒力 ーリットを途中 2 本ブースターとして使用したり, 手装 填をスーパーローダーによる機械装填に変えてみたりし たが顕著な効果はあがらなかつた。したがつて現在では $\mathrm{t}$ 当り装薬量の減少と, $\mathrm{AN}-\mathrm{FO}$ の完爆を考慮して $\mathrm{W} \times$ $\mathrm{S}=2.5 \mathrm{~m} \times 2.5 \mathrm{~m}, 3$ 段分散装薬, MS 発破, 1 次で 100 $\mathrm{g}$, 爆破係数 0.270 で行なつている。

(八) ガマの所ではできるだけ孔壁に密着させるため

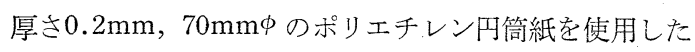
ところ, AN-FO が基準通り装填できるようになり 100 \%使用が可能となつた。

考察：（i）荒れ孔の場合カーリットでは途中でひつ かかりたびたび再装填の必要があつたが，AN-FO では バラ装薬のためなくなり装填能率が向上した。

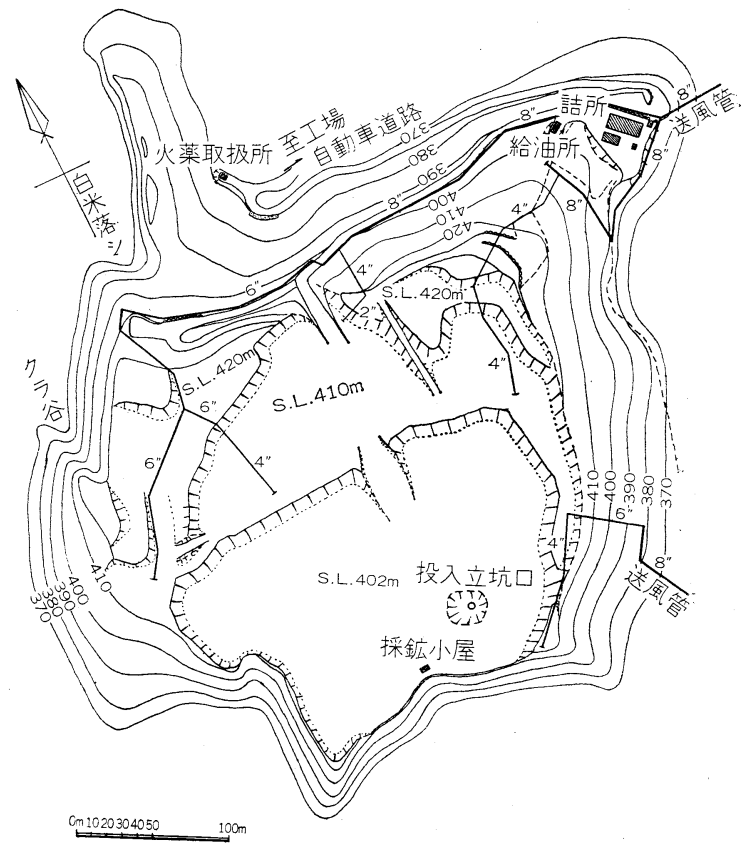

第 2 図山頂平面図

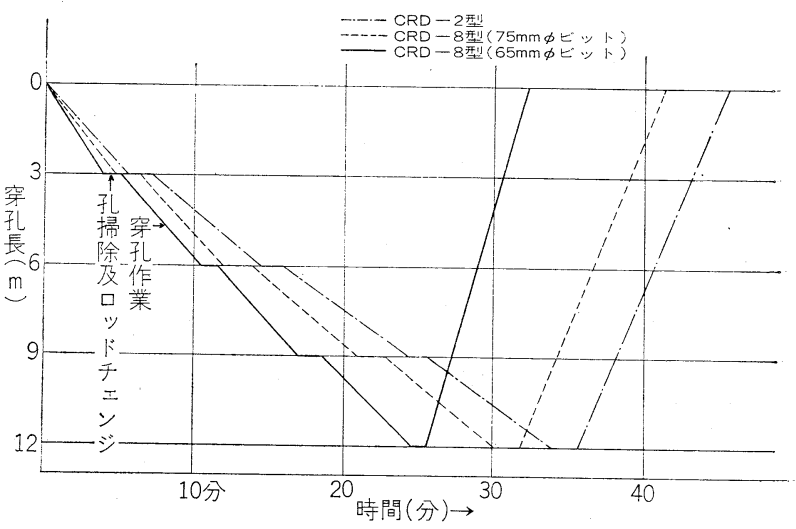

第3図クローラドリル穿孔状況

(ii） $\mathrm{t}$ 当り爆薬費がカーリット27円，AN-FO 11.7 円とAN-FO 使用のため57\%減少した。

\section{4. 小割発破における $\mathrm{AN}-\mathrm{FO}$ の利用}

\section{経過}

（1）カーリット：20mm $\phi \times 50 \mathrm{~g}$ の 5 号黒 カーリッ 卜を小割する石の大きさに順じて分割して電気発破して いる。

（2） AN-FO：40 年 5 月より竹製計量カップを使用 して孔中に流し込み 6 号電気雷管のみで起爆させてお り, 発破効果, 作業能率等カーリットに比較してほとん ど変わらない。現在小割発破における $\mathrm{AN}-\mathrm{FO}$ の利用率 は 42 年 $1 \sim 6$ 月平均 $90 \%, \mathrm{t}$ 当り爆薬使用量は $5 \mathrm{~g}$ であ る。 
考察：（ｉ） 発破効果，作業能率等はカーリットに比 較して大差なかつた。

(ii） 水孔に対しては,ブローパイプで吹かすこと,て い䄈いにタンピングを実施することで充分利用できる。

(iii） $20 \mathrm{~mm} \phi$ のポリエチレン袋に入れて装填するこ を検討する。(風雨の際使用できるよう)

(iv) タンピングの際電気雷管を引張り上げぬよう注 意が必要である。

\section{5. 切羽端部（残壁）処理発破に おける AN-FO の利用}

\section{経過}

（1） カーリット：岩盤の状態に応じて 5 号黒カーリ ット $20 \mathrm{~mm} \phi \times 50 \mathrm{~g}$ および $25 \mathrm{~mm} \phi \times 100 \mathrm{~g}$ 使用し飛石 防止のため, 弱装薬にして，MS 発破を実施していた。

(2) AN-FO：全体から 見れば非常に少なく全火薬 使用量の多くて $2 \%$ 前後であり，また使用環境が他に比 べて悪い。利用率をあげる対策として

（イ）破砕帯では孔壁が荒れて装填ホースが入りにく いので，ホースをできるだけ真直ぐに使用する。また孔 径の細いものの使用を検討する。

（ロ） $28 \mathrm{~kg}$ 入 3 輪車付小型スーパーローダーを購入 し装填機に機動性をもたせた。

（ハ）残壁上げ孔に対してはガンチャージャに小孔を あけることで能率を上げるようにした。

考察 : ポリエチレン袋等の利用により基準どおり ANFO 装薬が可能なので, ほとんど切換えが可能である。

第 2表 (1) AN-FO 使用比率

\begin{tabular}{|c|c|c|c|c|c|c|c|c|c|c|c|}
\hline \multirow{2}{*}{ 年 } & \multicolumn{4}{|c|}{$A N-F O$} & \multicolumn{4}{|c|}{$m-9,1$} & \multicolumn{3}{|c|}{ A N - F O 使用比率 } \\
\hline & 1 - 次 Kg & $t$ 当g & 2 次 $\mathrm{Kg}$ & $t$ 当g & 1 次 Kg & $t$ 当g & 2 次 $K g$ & $t$ 当如 & 1 次\% & 2 次\% & 計 $\%$ \\
\hline 39年6月 & 225 & 3 & - & & 7764 & 113 & 549 & 8 & 2.8 & - & 2.6 \\
\hline 7 & 4219 & 44 & - & & 5021 & 52 & 411 & 4 & 45.6 & - & 43.2 \\
\hline 8 & 12791 & 117 & - & & 3062 & 28 & 480 & 4 & 80.3 & - & 77.6 \\
\hline 9 & 7740 & 117 & - & & 2513 & 38 & 245 & 4 & 75.3 & - & 73.4 \\
\hline 10 & 10271 & 101 & - & & 3140 & 31 & 350 & 3 & 76.7 & - & 74.7 \\
\hline 11 & 7751 & 75 & - & & 2612 & 26 & 314 & 3 & 74.9 & - & 72.6 \\
\hline 12 & 8910 & 97 & - & & 1743 & 19 & 371 & 4 & 83.6 & - & 80.9 \\
\hline 40 年1月 & 7290 & 77 & - & & 1278 & 13 & 373 & 4 & 84.3 & - & 80.9 \\
\hline 2 & 8944 & 85 & - & & 1891 & 18 & 369 & 4 & 82.5 & - & 79.6 \\
\hline 3 & 6896 & 109 & - & & 1354 & 21 & 275 & 5 & 83.6 & - & 80.8 \\
\hline 4 & 8224 & 75 & - & & 1836 & 17 & 295 & 3 & 82.1 & - & 79.7 \\
\hline 5 & 6604 & 77 & 101 & 1 & 1678 & 20 & 219 & 2 & 79.7 & 28.2 & 77.6 \\
\hline 6 & 5389 & 75 & 270 & 4 & 1198 & 17 & 20 & - & 81.9 & 82.0 & 82.0 \\
\hline 7 & 8690 & 89 & 288 & 3 & 1577 & 16 & 130 & 2 & 85.1 & 65.6 & 83.8 \\
\hline 8 & 7338 & 87 & 323 & 4 & 1281 & 15 & 103 & 1 & 90.9 & 72.5 & 841 \\
\hline 9 & 4550 & 74 & 254 & 4 & 1221 & 20 & 115 & 2 & 79.0 & 66.2 & 77.9 \\
\hline 10 & 11291 & 101 & 667 & 6 & 1730 & 16 & 70 & 1 & 86.7 & 78.9 & 86.2 \\
\hline 11 & 8321 & 104 & 454 & 5 & 1145 & 14 & 98 & 2 & 88.0 & 77.2 & 87.7 \\
\hline 12 & 8259 & 102 & 450 & 6 & 1059 & 13 & 58 & 1 & 88.7 & 85.7 & 88.6 \\
\hline 41 年1月 & 7912 & 78 & 453 & 5 & 1051 & 10 & 70 & 1 & 88.2 & 86.6 & 882 \\
\hline 2 & 10027 & 97 & 494 & 4 & 1283 & 12 & 47 & - & 88.5 & 87.4 & 885 \\
\hline 3 & 10999 & 98 & 490 & 5 & 1173 & 10 & 73 & 1 & 90.7 & 84.4 & 90.4 \\
\hline 4 & 8744 & 97 & 415 & 4 & 937 & 10 & 67 & 1 & 90.4 & 86.2 & 90.0 \\
\hline 5 & 8409 & 88 & 590 & 6 & 1206 & 13 & 46 & - & 87.6 & 92.8 & 88.0 \\
\hline 6 & 9317 & 88 & 517 & 5 & 1618 & 15 & 72 & 1 & 85.1 & 86.4 & 85.2 \\
\hline 7 & 10077 & 99 & 486 & 5 & 1728 & 17 & 49 & - & 85.1 & 91.0 & 85.2 \\
\hline 8 & 9704 & 86 & 525 & 5 & 1561 & 14 & 76 & 1 & 86.4 & 87.5 & 86.5 \\
\hline 9 & 10247 & 103 & 499 & 5 & 1644 & 17 & 71 & 1 & 86.0 & 87.6 & 86.1 \\
\hline 10 & 12239 & 115 & 534 & 5 & 1386 & 13 & 45 & - & 90.2 & $9 \cdot 1.2$ & 90.3 \\
\hline 11 & 10529 & 102 & 587 & 6 & 1119 & 10 & 42 & - & 90.2 & 93.5 & 90.3 \\
\hline 12 & 15689 & 109 & 893 & 6 & 1718 & 12 & 50 & - & 89.6 & 94.8 & 902 \\
\hline 4 2年 1 月 & 15556 & 119 & 651 & 5 & 693 & 5 & 30 & - & 95.7 & 83.6 & 94.3 \\
\hline 2 & 14783 & 107 & 551 & 4 & 430 & 3 & 28 & -- & 97.2 & 89.8 & 97.0 \\
\hline 3 & 14037 & 100 & 376 & 3 & 675 & 5 & 16 & - & 95.4 & 89.1 & 95.3 \\
\hline 4 & 11567 & 105 & 379 & 4 & 964 & 9 & 63 & - & 92.6 & 85.9 & 922 \\
\hline 5 & 9379 & 87 & 655 & 6 & 520 & 5 & 29 & - & 93.8 & 95.6 & 94.9 \\
\hline 6 & 12616 & 94 & 609 & 5 & 590 & 5 & 26 & - & 95.7 & 96 & 95.7 \\
\hline
\end{tabular}

第 2表（2）丁場別 AN-FO 使用比率

\begin{tabular}{|c|c|c|c|c|c|c|c|c|c|c|c|c|}
\hline \multirow{2}{*}{ 月年乎別 } & \multicolumn{3}{|c|}{$420 \mathrm{M} \ddot{\bullet}$} & \multicolumn{3}{|c|}{$410 \mathrm{M}$ ベンチ } & \multicolumn{3}{|c|}{420 Mベンチ } & \multicolumn{2}{|l|}{ 残 } & 壁 \\
\hline & 1 次 & 2 次 & 小計 & 1 次 & 2次 & 小計 & 1 次 & 2 次 & 小計 & 1 次 & 2次 & 小計 \\
\hline $41 / 5$ & $91 \%$ & 95.8 & 91.2 & 93.0 & 90.7 & 92.8 & $\%$ & $\%$ & & 36.9 & $92 \%$ & 52.1 \\
\hline 6 & 91.2 & 79.5 & 90.2 & 92.1 & 84.0 & 91.9 & & & & 47.2 & 99.0 & 72.3 \\
\hline 7 & 92.0 & 83.5 & 91.4 & 91.7 & 96.2 & 91.9 & & & & 64.4 & 89.8 & 71.7 \\
\hline 8 & 89.7 & 81.5 & 89.4 & 90.9 & 89.5 & 91.0 & & & & 41.8 & \begin{tabular}{|l|l|}
9 & 1.0
\end{tabular} & 68.0 \\
\hline 9 & 90.3 & 87.3 & 90.2 & 89.7 & 85.2 & 89.6 & & & & 73.2 & 93.0 & 75.0 \\
\hline 10 & 90.7 & 75.5 & 90.1 & 91.7 & 94.4 & 91.8 & & & & 28.4 & 87.7 & 30.8 \\
\hline 11 & - & - & - & 91.7 & 93.0 & 92.2 & & & & 712 & 95.5 & 71.5 \\
\hline 12 & - & - & - & 91.0 & 95.1 & 91.2 & 87.4 & 92.3 & 87.5 & 100.0 & 77.8 & 88.6 \\
\hline $42 / 1$ & - & - & - & 95.4 & 97.2 & 95.5 & 96.3 & 86.6 & 96.0 & - & - & - \\
\hline 2 & - & - & - & 96.5 & 75.5 & $96: 2$ & 97.8 & 97.3 & 97.5 & 84.1 & 97.4 & 87.3 \\
\hline 3 & - & - & - & 92.6 & 91.4 & 92.5 & 95.6 & 94.9 & 95.6 & 75.7 & 100.0 & 76.2 \\
\hline & - & - & - & - & - & - & 94.9 & 86.9 & 93.0 & 50.2 & 58.2 & 503 \\
\hline$\underset{11}{5 \sim 42 / 4}$ & 90.8 & 83.7 & 90.4 & 92.4 & 89.3 & 92.3 & 94.4 & 91.6 & 93.9 & 57.5 & 89.2 & 67.4 \\
\hline 5 & - & - & - & - & - & - & 95.3 & 97.0 & 95.4 & 93.0 & 95.1 & 93.1 \\
\hline & - & - & - & - & - & - & 95.6 & 97.2 & 95.8 & 95.1 & 89.6 & 94.8 \\
\hline $\begin{array}{c}415 \sim 42 / 6 \\
\text { 平㚬 }\end{array}$ & 90.8 & 83.7 & 90.4 & 92.4 & 89.3 & 92.3 & 94.7 & 93.7 & 94.4 & 63.1 & 88.7 & 71.4 \\
\hline
\end{tabular}

\section{6. 香春鉱山における $\mathrm{AN}-\mathrm{FO}$ の使用 比率について}

試験を開始して以来，現在までの月別使用比率を 1 次 2 次に分けて見ると第 2 表のとおりである。最近 6 力月 (42年 1 月より 6 月まで) では最大 $97 \%$, 最小 $92.2 \%$, 平均 $95 \%$ と使用限度まで消費している。

\section{AN-FO の機械装填について}

装填機の種類：( i ) 三菱スーパーローダM20型：3 台, 容量 $28 \mathrm{~kg}$, 車輪付, 重量 $40 \mathrm{~kg}$, 用途：クローラ上げ 孔，トーホール装填用

(ii) 三菱ガンチャージャ： 1 台, 容量 $17 \mathrm{~kg}$, 重量 $21 \mathrm{~kg}$ ，用途：小孔径傾斜面の上げ孔

考察：( i ) M-20 型小型スーパーローダは軽量で機 動性がある。

(ii） ガンチャージャはエジェクタ型であるため入気 と排気のバランスがとれないと装填不能のため，ホース 径 $19 \mathrm{~mm}$ ではビットゲージ $32 \mathrm{~mm}$ 以上を必要としたが， エジェクタ出口のホースに $2 \mathrm{~mm} \phi$ の小孔 40 コあけてエ ヤーを逃してやりビットゲージ $29 \mathrm{~mm}$ で装填能率を向上 させることができた。

\section{8. $\mathbf{A N}-\mathbf{F O}$ 使用上の今後の問題点について}

前述のように当鉱山では全面的に AN-FO に切換え 現在に至つているが，今後更に $\mathrm{AN}-\mathrm{FO}$ の使用率を増 加させ採掘原価の低減を計るためには次の 3 つが問題と なる。

(i) 雨天時における $\mathrm{AN}-\mathrm{FO}$ の使用

（イ）水孔に詨しては充分エヤーで掃除しさらにタン ピングは晴天時よりもていねいにロ元まで行なう。

(口) 発破孔への雨水の流入を防止する。

（ハ）ポリエチレン袋に AN-FOを入れて後装填す る。 
第3 表 $\mathrm{AN}-\mathrm{FO}$ の諸性能

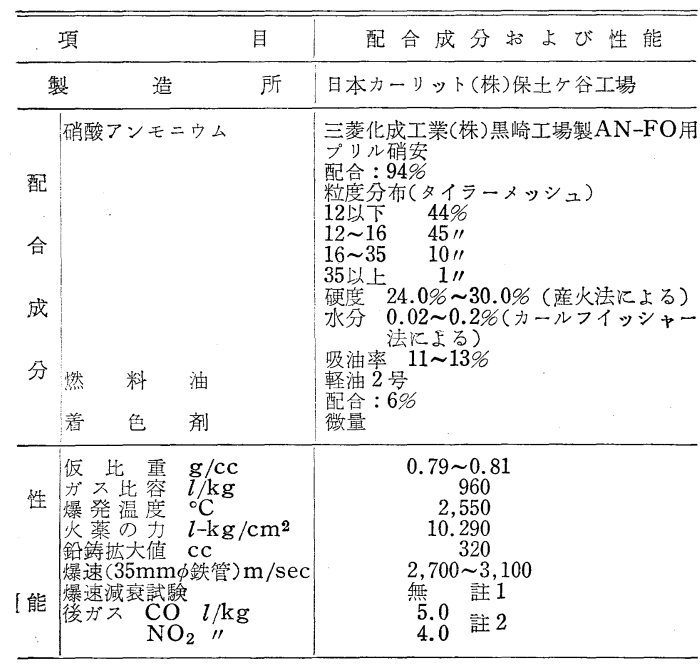

(註) 1. 爆速減衰訊験は内径 $27 \mathrm{~mm}$, 長さ $1.0 \mathrm{~m}$ 鉄管飞密填し, プライ マーは酎水紫カーリット $25 \mathrm{~mm} \times 50 \mathrm{~g}$ で起爆し, 起爆位置よ り $10 \mathrm{~cm}, 50 \mathrm{~cm}, 90 \mathrm{~cm}$ の位置で測定した值

2. 後ガスについては, 容積 $50 \mathrm{~cm}^{3}$ の密閉室で爆発させ, 北川式 の検知管で測定した値

\section{神岡鉱山における $\mathrm{AN}-\mathrm{FO}$}

\section{1. 緒言}

神岡鉱業所杤洞坑では AN-FO を昭和39年 7 月から採 鉱预よび開坑の一部に採用し，現在では全爆薬使用量の うち約55\%を占めており，コストダウンに大きく貢献し ている。AN-FO を採用するまでの経緯については既に 第16回掠よび第17回採鉣現場担当者会議講演集で詳しく のべているのでここでは省略して，その後の $\mathrm{AN}-\mathrm{FO} に$ よる操業のうち特に上向孔への装填を中心に報告する。

\section{2. 採鉱 法}

杤洞坑の採鉱法はサブレベルストーピングが $60 \%$ ，コ ンバインドブロックケービングが30\%，その他 $10 \%$ であ る。これら採鉣法は AN-FOを有効に使用することで一 層の效力を発揮している。すなわら，従来 $38 \mathrm{~mm}$ であつ た装薬孔が大型さく岩機の採用とともに $75 \mathrm{~mm}$ となり， 価格，爆速，装填密度の点で $\mathrm{AN}-\mathrm{FO}$ 使用上の好条件と なり第1表に示すごとく画期的な能率の向上をもたらし ている。また当坑の代表的採鉣法であるサブレベルスト 一ピングの穿孔型式は従来はベンチカット後の垂直下向 平行型をとつていたが，現在は垂直扇形型を採用し，工

* 三井金属鉱業株式会社神岡釷業所杤洞坑辰

** 三井金属鈗業株式会社神岡鈗業所杤洞坑坑長代理 (ii) プライマーの減少

（イ）クローラ発破では 3 段分散装薬で AN-FO切換 え当初は $10 \%$ 使用していたが現在では $2 \%$ に減つてい る。さらに爆速の早い爆薬を使用してプライマーの量を 減少させる。

（ロ）プライマーに精製された AN-FOを使用してカ ーリットを使用しない。

(iii) AN-FO 価格の低減

(イ） AN-FO の山元混合

$\mathrm{t}$ 当り爆薬費を減少させるには，AN-FO の価格低減以 外にはなく，このためには山元混合は魅力があり今後鉱 山保安法の管理下で AN-FOの山元混合が認められるよ ら切望する。

(ロ)メーカーの值下げ

さらにメーカーの合理化努力によるコストダウンを期 待する。

\section{の上向孔への装填について}

$\begin{array}{llll}\text { 佐 } & \text { 藤 } & \text { 一 } & \text { 夫 } \\ \text { 塚 } & \text { 本 } & \text { 俊 } & \text { 六** }^{*}\end{array}$

程の悪いベンチカットを無くしている。さらに AN-FO の有利性を活汃し装薬孔は現在の $75 \mathrm{~mm} \phi$ を独立回転式 5 "級大型さく岩機の採用により 100 125mm な能率の上昇を図るように計画している。長孔能率比較 および驾孔型式は第1表および第1図のごとくである。
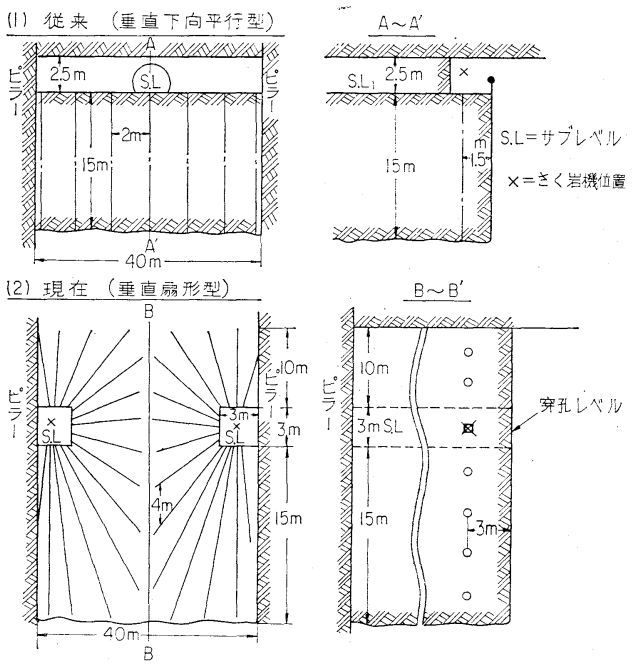

第 1 図 $(\mathbf{A})$ 